\title{
COLLOIDS \\ Characteristics of nanosized polyaluminum chloride coagulant prepared by electrolysis process
}

\author{
Hui-Juan Liu, Jiu-Hui Qu*, Cheng-Zhi Hu, Su-Juan Zhang \\ State Key Laboratory of Environmental Aquatic Chemistry, Research Center for Eco-Environmental Sciences, Chinese Academy of \\ Sciences, Beijing 100085, People's Republic of China
}

Received 17 June 2002; accepted 11 November 2002

\begin{abstract}
Polyaluminum chloride (PAC) has become a focus of many studies involving coagulation because of its advantages over traditional coagulants. In this study, a novel method involving an electrolysis process for preparing of PAC was developed. The products were characterized using ${ }^{27} \mathrm{Al}$ NMR spectroscopy, dynamic light scattering (DLS) and transmission electron micrograph (TEM). Results indicated that the electrolysis process provided favorable conditions for the formation of significant quantities of active species $\left(\mathrm{Al}_{13}\right.$ polymer) at relatively high concentrations of total $\mathrm{Al}$ $\left(\mathrm{Al}_{\mathrm{T}}\right)\left(0.2-2.0 \mathrm{~mol}^{-1}\right)$. For each concentration of $\mathrm{Al}_{\mathrm{T}}$, there was an optimum molar ratio of $\mathrm{OH} / \mathrm{Al}(n)$ for formation of $\mathrm{Al}_{13}$. The $\mathrm{Al}_{13}$ species was stable for more than 6 months in solution when the $n$ value was $<2.0$. However, in solutions with $n$ values above 2.2 , the $\mathrm{Al}_{13}$ species gradually converted to other polynuclear forms that were not detectable by ${ }^{27} \mathrm{Al}$ NMR spectroscopy. The results of DLS and TEM showed that the particles existing in PAC prepared by the electrolysis process were in the nanometer size range.
\end{abstract}

(C) 2002 Elsevier Science B.V. All rights reserved.

Keywords: Preparation; Polyaluminum chloride; Electrolysis process; $\mathrm{Al}_{13}$ polymer; Stability

\section{Introduction}

Concentrated solutions of partially prehydrolyzed aluminum salts such as polyaluminum chloride (PAC) are commonly used as flocculants for water treatment and other coagulation-flocculation applications [1-3]. Much attention has been paid to partially prehydrolyzed $\mathrm{Al}$ salt in recent

\footnotetext{
* Corresponding author. Tel.: +86-10-62849151; fax: +8610-62923558.

E-mail address: hjliu@mail.rcees.ac.cn (J.-H. Qu).
}

years because of their higher efficiency and relatively lower costs compared with the traditional coagulants. A good understanding of the characteristics of PAC is of benefit in optimizing operational conditions of water treatment. It is generally thought that the higher efficiency of these flocculants depends on characteristics such as the content of active species and the particle size distribution. It has been demonstrated that the active species responsible for coagulation or precipitation is the highly charged polymeric aluminum $\mathrm{Al}_{13}\left(\left[\mathrm{AlO}_{4} \mathrm{Al}_{12}(\mathrm{OH})_{24}\left(\mathrm{H}_{2} \mathrm{O}\right)_{12}\right]^{7+}\right)$ species [4-8]. $\mathrm{Al}_{13}$ is composed of one tetrahedral center 
surrounded by 12 octahedral Al units [9-14]. Besides the characteristic of higher positive charge $(+7)$ and resultant strong ability to bind to particles, $\mathrm{Al}_{13}$ polymer possess fairly stable structure against hydrolysis before adsorption to particle surfaces. These properties contribute to their superior behavior in coagulation.

PAC is an intermediate product in the hydrolysis, polymerization, gelation and precipitation process of aluminum. The tendency for $\mathrm{Al}_{13}$ formation in partially neutralized aluminum solutions has been shown to be a function of solution composition and synthesis conditions [15-18]. Bertsch et al. [15] presented a tenable model wherein the formation of $\mathrm{Al}_{13}$ depends critically on an interfacial disequilibrium between the acidic, Al-containing solution and the base being injected into it. Ordinarily, the main PAC preparation processes include acid hydrolysis [19] utilizing aluminum and alumina refined from clay and coal stone as the raw material, acidifying aluminum hydrate from sodium aluminate in inadequate hydrochloric acid [19], and neutralization, electrolysis [20], and heat decomposition using aluminum chloride as the raw material [19]. Recent research has shown that the electrolysis process could produce effective PAC [21-24]. However, the role of their physical properties, especially the content of active species, the stability of the active species and the particle size distribution, remains unclear. It is believed that the active species and the particle size distribution are of particular importance in the behaviour and efficiency of PAC.
The first purpose of this work is to ascertain the optimum parameters for preparation of highcontent, stable active species $\left(\mathrm{Al}_{13}\right)$ in the electrochemical preparation of PAC at relatively high Al concentration $\left(\sim 2.0 \mathrm{~mol} \mathrm{l}^{-1}\right)$. The second purpose is to characterize the particle size distribution of the PAC prepared by the electrochemical process. In this preliminary study, we aim to obtain some important insights into the electrochemical formation of nanosized PAC. In a late study, we focus on the coagulation mechanisms and efficiency of flocculation using electrochemically generated PAC.

\section{Materials and methods}

\subsection{Electrochemical preparation of $P A C$}

The schematic view of the electrochemical reactor used for PAC preparation is illustrated in Fig. 1. It consists of an electrolytic rectifier (GCA12-16, China) and an electrolytic cell made of organic glass. Five sheets of $\mathrm{Al}\left(110 \times 60 \mathrm{~mm}^{2}\right)$ were used as anodes while five sheets of $\mathrm{Fe}(110 \times$ $60 \mathrm{~mm}^{2}$ ) were used as cathodes. A $700 \mathrm{ml} \mathrm{AlCl} 3$ aqueous solution of designated concentration was added to the electrolysis reactor. Electrolysis was then carried out at a constant current density of $1.1 \mathrm{~A} \mathrm{dm}^{-2}$ as recommended by Lu et al. [23]. A pump was used to circulate the solution and to increase mass transfer. Finally, the product was aged for $48 \mathrm{~h}$ to stabilized the PAC. The final product was a clear aqueous solution with the

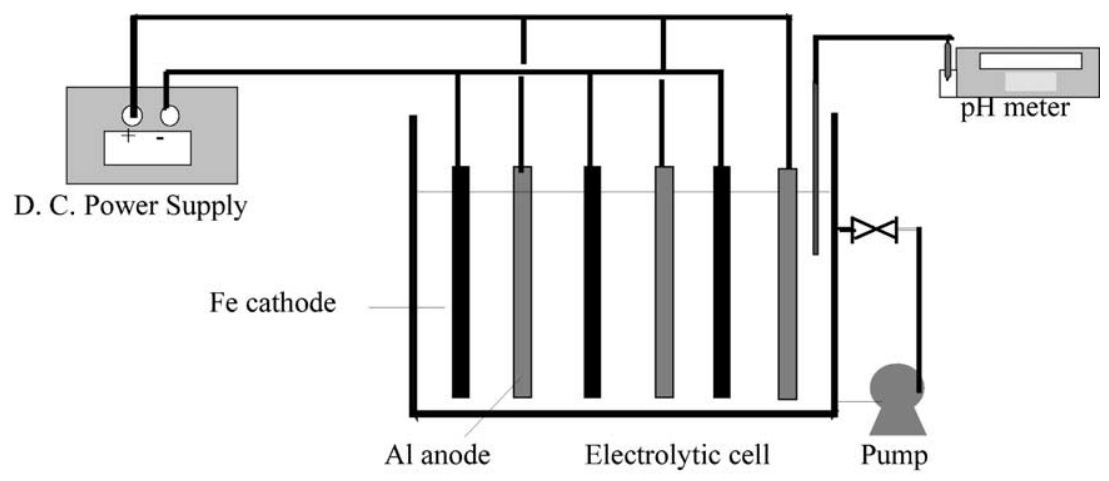

Fig. 1. The schematic view of electrochemical reactor for PAC preparation. 
following characteristics: $\mathrm{Al}_{\mathrm{T}}=0.2-2.0 \mathrm{~mol}^{-1}$, $n=0-2.8$. PAC prepared at $n$ values from 0 to 2.2 were stable with no sign of sedimentation after 6 months.

\subsection{Analytical methods}

\subsubsection{NMR spectrometer}

${ }^{27} \mathrm{Al}$ NMR spectroscopy was used to characterize the $\mathrm{Al}$ species with ${ }^{27} \mathrm{Al}$ NMR spectra obtained on a VARIAN ${ }^{\text {UNITY }}$ INOVA (500 MHz) spectrometer. Samples were placed in $5 \mathrm{~mm}$ tubes and the spectra generated at $20{ }^{\circ} \mathrm{C}$. To estimate the distribution of various species in solution, selected samples and standard solutions of known monomeric $\mathrm{Al}$ concentration were run using a coaxial sample tube, with a $0.2 \mathrm{M} \mathrm{Na}$ aluminate solution in the inner insert as reference. The intensities for ${ }^{27} \mathrm{Al}$ signals relative to the aluminate reference were used for calculating the Al concentration's corresponding signals. There were three signals in the ${ }^{27} \mathrm{Al}$ NMR spectra (Fig. 2). The intensities of the $0 \mathrm{ppm}$ resonance represented quantitative determinations of the monomeric $\mathrm{Al}$ in aluminum solution, that of $63 \mathrm{ppm}$ resonance represented quantitative determinations of the $\mathrm{Al}_{13}$ polymer of alum solution. The $80 \mathrm{ppm}$ resonance represented $\mathrm{Na}$ aluminate. The concentration for the $63 \mathrm{ppm}$ signal was multiplied by 13 to obtain the concentration of $\mathrm{Al}_{13}$. It has been generally accepted that for the $\mathrm{Al}_{13}$ complex, only the tetrahedrally coordinated $\mathrm{Al}$ at the center of the structure yields the signal at $63 \mathrm{ppm}[1,15]$.

\subsubsection{Dynamic light scattering}

The particle size distribution in the final electrolyte solution was measured using a servomotorcontrolled light scattering goniometer (Brookhaven BI200SM, USA). The incident light source was a $35 \mathrm{~mW} \mathrm{He}-\mathrm{Ne}$ laser operating at a $623.8 \mathrm{~nm}$ wavelength with vertical polarization. Prior to dynamic light scattering (DLS) determination, PAC samples were purified by filtering with 0.45 $\mu \mathrm{m}$ Whatmann membranes $4-5$ times. The purified samples were then transferred into the sample cell for further determination.

The $\mathrm{pH}$ value of the solutions was measured with a $\mathrm{pH}$ meter (Orion $720 \mathrm{~A}, \mathrm{USA}$ ). $\mathrm{Al}_{\mathrm{T}}$ and the

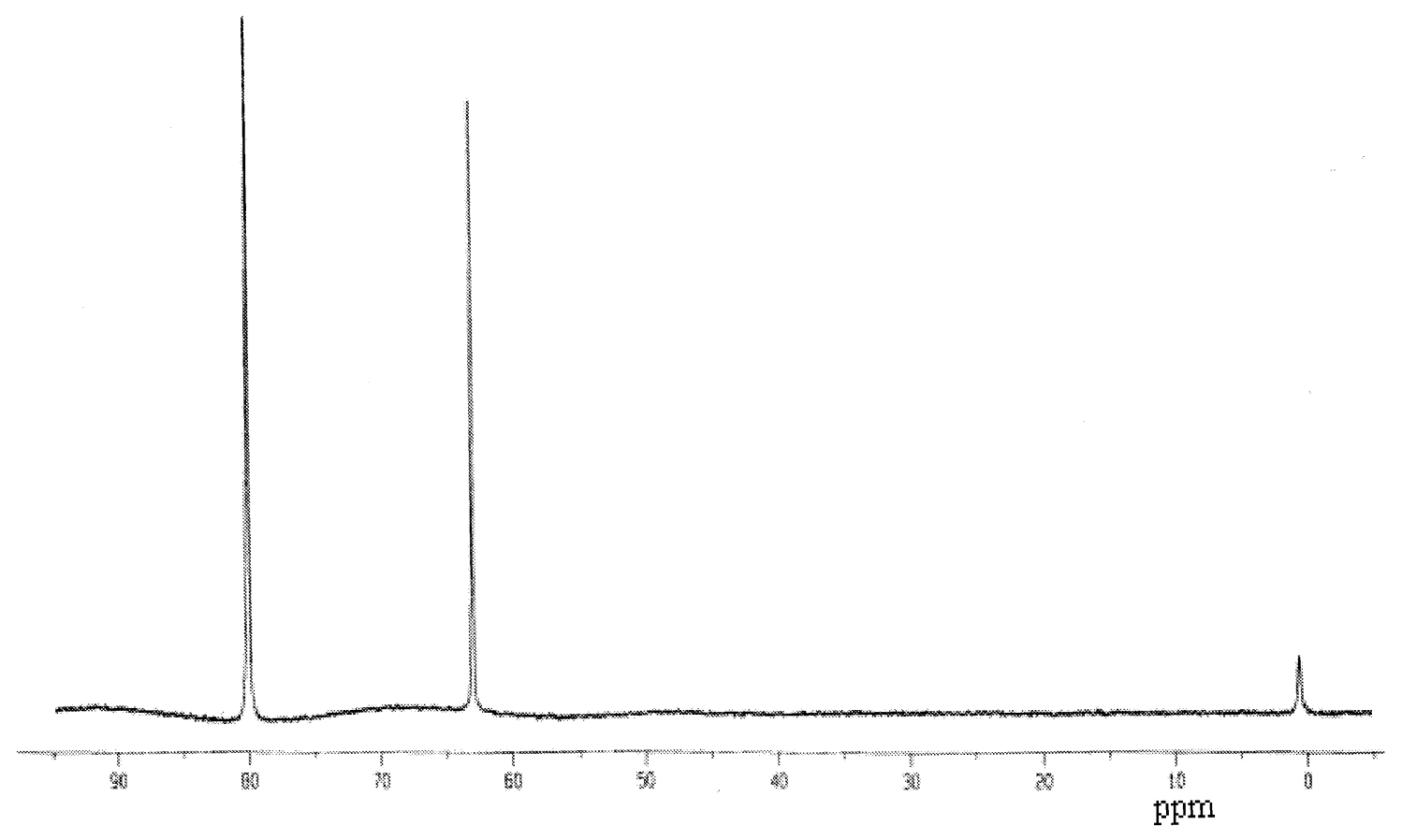

Fig. 2. ${ }^{27} \mathrm{Al}$ NMR spectra of PAC prepared by electrochemical process. 
$n$ value were determined by titrimetric methods, and details of the analytical procedure are given elsewhere [19]. Transmission electron micrographs (TEMs) were obtained using a HITACHI H-600 instrument.

\section{Results and discussion}

\subsection{Active species formation in PAC preparation}

$\mathrm{Lu}$ et al [23] illustrated the principles of PAC preparation by the electrolysis process. When the electrolysis is carried out with direct current in the reactor, $\mathrm{Al}^{3+}$ and $\mathrm{OH}^{-}$are generated at the anode and cathode, respectively. The reaction, which then takes place in the electrolysis cell, is:

$\mathrm{Al}+\mathrm{H}_{2} \mathrm{O}+\mathrm{AlCl}_{3} \rightarrow \mathrm{Al}_{m}(\mathrm{OH})_{n} \mathrm{Cl}_{(3 m-n)}+\mathrm{H}_{2} \uparrow$

$\mathrm{Al}_{m}(\mathrm{OH})_{n} \mathrm{Cl}_{(3 m-n)}$ represents the intermediate product which continues to hydrolyze to $\mathrm{Al}(\mathrm{OH})_{3}$ (Eq. (2)). If the generation and reaction of ionized $\mathrm{OH}^{-}$and $\mathrm{Al}^{3+}$ are regulated at a proper rate, it is possible to control the ensuring processes of hydrolysis, polymerization, gelation and precipitation of aluminum species in order to obtain PAC containing as much $\mathrm{Al}_{13}$ as possible.

$$
\begin{aligned}
\mathrm{Al}^{3+} & \rightarrow \text { monomeric } \rightarrow \mathrm{Al}_{13} \text { polymer } \\
& \rightarrow \text { colloid or precipitated } \mathrm{Al} \rightarrow \mathrm{Al}(\mathrm{OH})_{3} \\
& \downarrow
\end{aligned}
$$

It is assumed by several authors [18,25] that the process of $\mathrm{Al}_{13}$ formation requires the presence of $\mathrm{Al}(\mathrm{OH})_{4}^{-}$as a precursor. Akitt and Farthing [25] assumed a very rapid $\mathrm{Al}(\mathrm{OH})_{4}^{-}$production under the inhomogeneous conditions at the solid-solution interface. During the electrolysis, $\mathrm{OH}^{-}$was generated at the surface of the cathode sheets that were arranged throughout the electrolysis reactor, leading to formation of $\mathrm{Al}(\mathrm{OH})_{4}^{-}$at the metalsolution interface with subsequent formation of $\mathrm{Al}_{13}$ polymers.

As the reaction continued, the $\mathrm{Al}_{13}$ polymer units gradually formed tenuous linear aggregates with $\mathrm{Cl}^{-}$acting to bridge the units. The proposed mechanism of forming $\mathrm{Al}_{13}$ aggregates through anion bridging is illustrated in Fig. 3 [26]. Small $\mathrm{Al}_{13}$ aggregates could transform to condensed aggregates with the transformation from $\left[\mathrm{Al}_{13}\right]_{n}$ to the poorly ordered solid phase(s) highly dependent on the concentration of $\mathrm{Al}_{\mathrm{T}}$ and neutralization ratio and the concentration of anions which act to neutralize the charge on the $\mathrm{Al}_{13}$ units and facilitate bridging. It is, therefore, important to confirm the optimum $n$ value associated with certain $\mathrm{Al}_{\mathrm{T}}$ concentrations. With optimal parameters, the PAC prepared by electrochemical process not only exhibited high $\mathrm{Al}_{13}$ content but was also stable with time.

\section{2. $A l_{13}$ content of $P A C$}

A series of PAC with total aluminum concentrations $\left(\mathrm{Al}_{\mathrm{T}}\right)$ of $0.2,1.0$ and $2.0 \mathrm{~mol}^{-1}$ at different $n$ were prepared by the electrolysis process. The percentage of $\mathrm{Al}_{13}$ in the solutions of varying of $\mathrm{Al}_{\mathrm{T}}$ as a function of $n$ is shown in Fig. 4. At the same concentration of $\mathrm{Al}_{\mathrm{T}}$, the

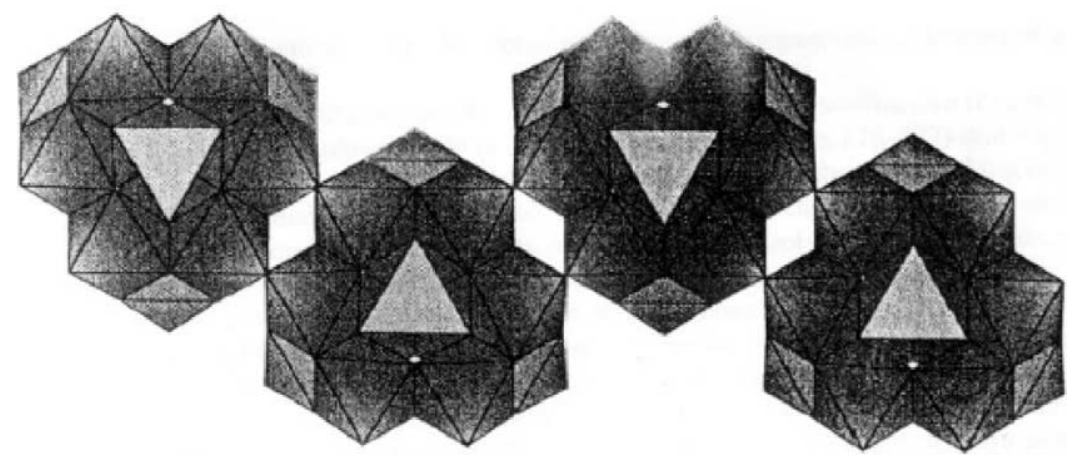

Fig. 3. Suggested structure of the small $\mathrm{Al}_{13}$ aggregates where individual units are bridged via anions. 
amount of $\mathrm{Al}_{13}$ increased as a function of $n$, and passed through a maximum before decreasing at the higher $n$ value. For different concentrations of $\mathrm{Al}_{\mathrm{T}}$, the optimum $n$ value yielding a high content of $\mathrm{Al}_{13}$ was slightly different. At $\mathrm{Al}_{\mathrm{T}}=2.0 \mathrm{~mol}^{-1}$ the maximum $\mathrm{Al}_{13}$ yield $\left(70.2 \%\right.$ of $\left.\mathrm{Al}_{\mathrm{T}}\right)$ was obtained at $n=2.2$. The maximum $\mathrm{Al}_{13}$ yield $\left(79.8 \%\right.$ of $\left.\mathrm{Al}_{\mathrm{T}}\right)$ was obtained at $n=2.4$ when $\mathrm{Al}_{\mathrm{T}}=1.0$ mol $1^{-1}$, whereas the maximum $\mathrm{Al}_{13}$ yield $\left(83.5 \%\right.$ of $\left.\mathrm{Al}_{\mathrm{T}}\right)$ was obtained at $n=2.5$ when $\mathrm{Al}_{\mathrm{T}}=0.2 \mathrm{~mol} 1^{-1}$. When $n$ was above these optimum values, the formation of $\mathrm{Al}_{13}$ rapidly decreased due to the formation of a colloidal, amorphous precipitate.

Inspection of the $\mathrm{Al}_{13}$ data reveals that formation of $\mathrm{Al}_{13}$ was favored by decreasing $\mathrm{Al}_{\mathrm{T}}$ (from 2.0 to $0.2 \mathrm{~mol}^{-1}$ ). This tendency is not consistent with the trend of $\mathrm{Al}_{13}$ formation at more dilute $\mathrm{Al}$ concentrations. Most other studies [18,27,28] of $\mathrm{Al}_{13}$ formation have utilized $\mathrm{Al}_{\mathrm{T}}$ concentrations below $0.01 \mathrm{~mol} \mathrm{l}^{-1}$ and proved that lowering $\mathrm{Al}_{\mathrm{T}}$ tended to produce lesser quantities of $\mathrm{Al}_{13}$. Parker and Bertsch [27] offered two possible explanations for the reduced quantities of $\mathrm{Al}_{13}$ at lower $\mathrm{Al}_{\mathrm{T}}$ values. First, concentrations of necessary precur- sors for formation, perhaps including the aluminate ion as well as a small oligomer, would likely be diminished in more dilute solutions, thus favoring colloidal $\mathrm{Al}$ formation over that of $\mathrm{Al}_{13}$. Alternatively, abundant $\mathrm{Al}_{13}$ forms initially but more rapidly aggregates and begins conversion to the colloidal form. These possible explanations are also suitable for the concentrated Al concentration. In concentrated $\mathrm{Al}$ solution, the quantity of small oligomers is abundant, so the precursor generation is the key parameter in the formation of $\mathrm{Al}_{13}$. The $\mathrm{Al}(\mathrm{OH})_{4}^{-}$precursor will produce at the solid-solution interface as in the following reaction:

$$
\begin{aligned}
& \mathrm{Al}^{3+}+4 \mathrm{OH}^{-} \rightarrow \mathrm{Al}(\mathrm{OH})_{4}^{-} \\
& K=\frac{\left[\mathrm{Al}(\mathrm{OH})_{4}^{-}\right]}{\left[\mathrm{Al}^{3+}\right]\left[\mathrm{OH}^{-}\right]^{4}} .
\end{aligned}
$$

Since the formation rate of $\mathrm{OH}^{-}$is determined by the current density, we can know that higher concentrations of $\mathrm{Al}$ can yield higher quantities of $\mathrm{Al}(\mathrm{OH})_{4}^{-}$as precursor of $\mathrm{Al}_{13}$. But it also tends to exhibit suboptimal yields of $\mathrm{Al}_{13}$ because increasing $\mathrm{Al}_{\mathrm{T}}$ results in greater degrees of supersaturation of $\mathrm{Al}(\mathrm{OH})_{4}^{-}$that might favor direct formation

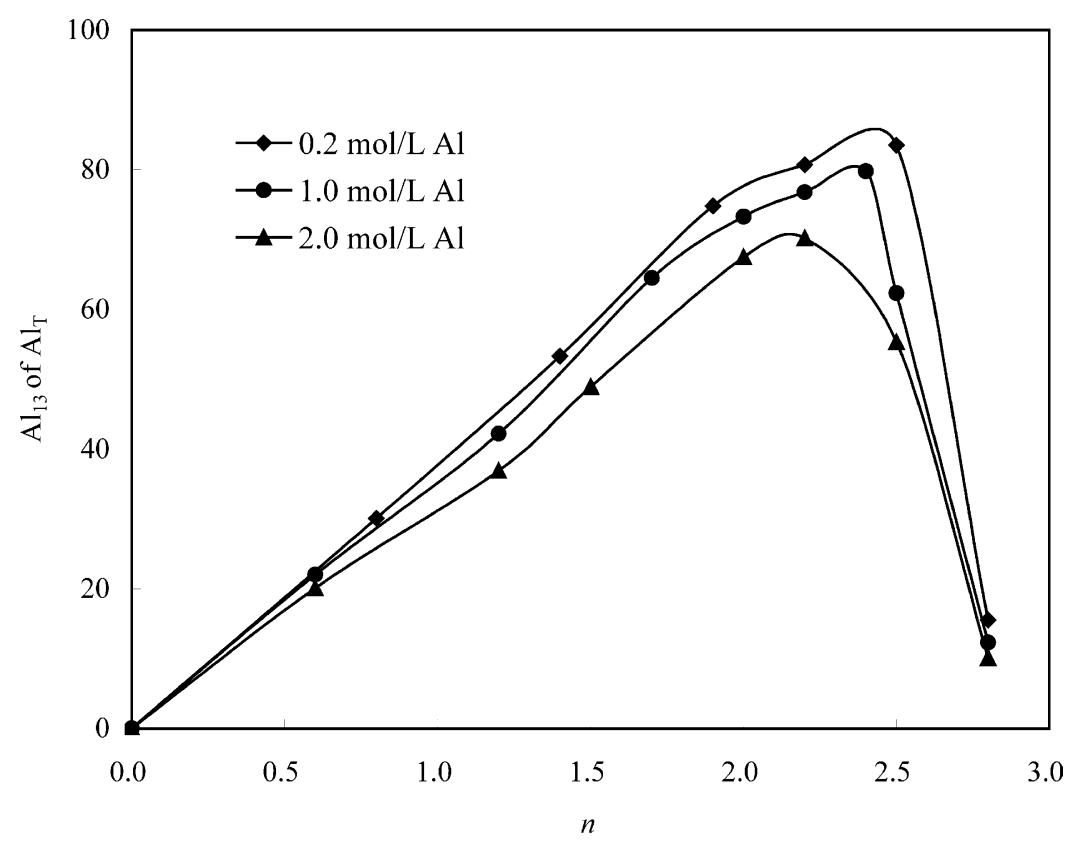

Fig. 4. Percentage of $\mathrm{Al}_{13}$ in PAC solutions of varying concentration of $\mathrm{Al}_{\mathrm{T}}\left(0.2,1.0\right.$, or $\left.2.0 \mathrm{~mol} 1^{-1}\right)$ as a function of $n$. 
of amorphous $\mathrm{Al}(\mathrm{OH})_{3}$ and/or gibbsite. These effects become much more pronounced with increasing concentrations of $\mathrm{Al}_{\mathrm{T}}$ and $n$ values.

\subsection{Stability of $P A C$}

PAC with high stability is appropriate for longterm storage and accelerating its potential for large-scale use. Although hydroxy aluminium polymers are metastable with respect to precipitation, they persist in solution for at least a few months [29]. Turner [30,31] demonstrated that the rate of neutralization played a critical role in the subsequent reactions taking place during aging. With rapid neutralization, the initial $\mathrm{OH}-\mathrm{Al}$ polymers gradually transformed to gibbsite, whereas slow neutralization led to the formation of stable polymers of similar $n$. Lu et al [23] has shown that the rate of base addition in the electrolysis process lies between the "one shot" addition and sequential "micro-injection".

Table 1 shows the results of $\mathrm{Al}$ species distribution with aging time for an $\mathrm{Al}_{\mathrm{T}}$ concentration of
$2.0 \mathrm{~mol}^{-1}$ and $n$ values of 1.2, 2.0, 2.2, and 2.5, respectively. For $n=1.2 \mathrm{PAC}$, the content of $\mathrm{Al}_{13}$ polymer accounted for $36.9 \%$ of the $\mathrm{Al}_{\mathrm{T}}$ at the end of the electrolysis ( 0 day). The increase of $\mathrm{Al}_{13}$ at the beginning of the aging time (0-2 days) is mainly due to further hydrolysis of the aluminum dissolved from anode but does not react with $\mathrm{OH}^{-}$completely in the electrolysis process. After 2 days aging, the content of $\mathrm{Al}_{13}$ polymer was stable and nearly no change with time was observed until 208 days of aging. For a fresh $(0$ day) PAC solution of $n=2.0$ and $2.0 \mathrm{~mol}^{-1}$ in $\mathrm{Al}_{\mathrm{T}}$, about $65.6 \%$ of the $\mathrm{Al}_{\mathrm{T}}$ was in the $\mathrm{Al}_{13}$ form. In the stages of aging, the content of $\mathrm{Al}_{13}$ increased a little, as found for $n=1.2$ solution. After 303 days of aging, some $\mathrm{Al}_{13}$ polymer rearranges into large polymers unobserved with the NMR technique. Formation of other polymers was evident from the increase in the amount of undetectable $\mathrm{Al}$, the disappearance of $\mathrm{Al}_{13}$, and the decrease of monomeric $\mathrm{Al}$ in solution. Even so, the content of $\mathrm{Al}_{13}$ was stable and accounted for above $60 \%$ of $\mathrm{Al}_{\mathrm{T}}$ after 302 days aging.

Table 1

Distribution change of various $\mathrm{Al}$ species in $\mathrm{PAC}\left(\mathrm{Al}_{\mathrm{T}}=2.0 \mathrm{~mol} \mathrm{1^{-1 }}\right)$ with aging time

\begin{tabular}{|c|c|c|c|c|c|}
\hline \multirow[t]{2}{*}{$n$} & \multirow[t]{2}{*}{ Aging time per day } & \multirow[t]{2}{*}{$\mathrm{pH}$} & \multicolumn{3}{|l|}{$\%$ of $\mathrm{Al}_{\mathrm{T}}$} \\
\hline & & & Monomeric & $\mathrm{Al}_{13}$ & Undetected \\
\hline \multirow[t]{4}{*}{1.2} & 0 & 2.78 & 55.2 & 36.9 & 7.9 \\
\hline & 2 & 2.82 & 54.8 & 37.2 & 8.0 \\
\hline & 30 & 2.71 & 51.3 & 35.4 & 13.3 \\
\hline & 208 & 2.79 & 50.5 & 34.3 & 15.2 \\
\hline \multirow[t]{5}{*}{2.0} & 0 & 3.01 & 22.2 & 65.6 & 12.2 \\
\hline & 2 & 3.12 & 19.7 & 67.2 & 13.1 \\
\hline & 30 & 3.28 & 18.9 & 62.1 & 19.0 \\
\hline & 255 & 3.25 & 19.2 & 61.6 & 19.2 \\
\hline & 302 & 3.16 & 16.8 & 60.8 & 22.4 \\
\hline \multirow[t]{5}{*}{2.2} & 0 & 3.26 & 10.8 & 70.2 & 19.0 \\
\hline & 2 & 3.31 & 7.2 & 72.3 & 20.5 \\
\hline & 30 & 3.42 & 7.9 & 60.6 & 31.5 \\
\hline & 281 & 3.38 & 7.7 & 42.1 & 50.2 \\
\hline & 373 & 3.50 & 7.0 & 33.6 & 59.4 \\
\hline \multicolumn{6}{|l|}{2.5} \\
\hline & 0 & 3.68 & 8.1 & 55.3 & 36.6 \\
\hline & 2 & 3.74 & 7.2 & 42.1 & 50.7 \\
\hline & 10 & 3.79 & 6.5 & 20.6 & 72.9 \\
\hline & 30 & 3.76 & 6.5 & 10.4 & 83.1 \\
\hline
\end{tabular}


Several studies [15,32-35] have shown that upon aging, structural rearrangements take place within the $\mathrm{Al}_{13}$ structure without the involvement of further hydrolysis and with the rate of rearrangement dependent on the concentration of $\mathrm{Al}$ and the $n$ value. Parthasarathy and Buffle [28] suggested that $0.01 \mathrm{M}$ solutions of $\mathrm{Al}_{13}$ seem to be stable for up to a year if the neutralization ratio, $n$, does not exceed a value of 2.5. Furrer et al [36] found from ${ }^{27} \mathrm{Al}$ NMR studies that homogeneous solutions of $1 \mathrm{mmol}^{-1} \mathrm{Al}_{13}$ at $n=2.46$ and $\mathrm{pH} 5$ could be stored at room temperature for at least 6 months without any noticeable transformations. If $n$ was increased above 2.5 , the dissolved $\mathrm{Al}_{13}$ units tend to aggregate, and at $n=3$, the precipitated $\mathrm{Al}_{13}$ was transformed into amorphous $\mathrm{Al}$ hydroxides within a few days [37].

From Table 1, it can be seen that when $n$ values were higher than 2.0, the $\mathrm{Al}_{13}$ was not stable, and transformed into colloidal aggregates. For the solutions of $n=2.2$, despite the high content of $\mathrm{Al}_{13}$ formed in the preparation process $(70.2 \%)$, the content of this species decreased to $42.1 \%$ after 281 days and to $33.6 \%$ after 373 days of aging. For the PAC of $n=2.5$, after 30 days of aging, only $10.4 \%$ of $\mathrm{Al}_{\mathrm{T}}$ remained as $\mathrm{Al}_{13}$.

\subsection{Particle size distribution of PAC prepared by electrochemical process}

A TEM of PAC $\left(\mathrm{Al}_{\mathrm{T}}=2.0 \mathrm{~mol} 1^{-1}, n=2.0\right)$ is shown in Fig. 5 and shows that the particles are distributed homogeneously in PAC prepared by the electrochemical process.

The particle size distribution of $\mathrm{PAC}\left(\mathrm{Al}_{\mathrm{T}}=2.0\right.$ mol $1^{-1}, n=1.5,2.0$ and 2.5) prepared by the electrolysis process was analyzed by DLS after 3 days of ageing. During the measurement, we found that the scattered intensity of samples with $n$ value of 1.5 was too low to obtain reasonable results. The PAC with larger $n$ values (2.0 and 2.5) exhibited intensities of between 1 and $50 \mathrm{Kcps}$. Distinct "size bands" were observed with the proportion of particles within observed size ranges and the mean diameter of the samples given in Table 2. For the $n=2.0$ sample, a small size band between 3 and $5 \mathrm{~nm}$, a second size band between 8 and $15 \mathrm{~nm}$, and a third band of large aggregates of

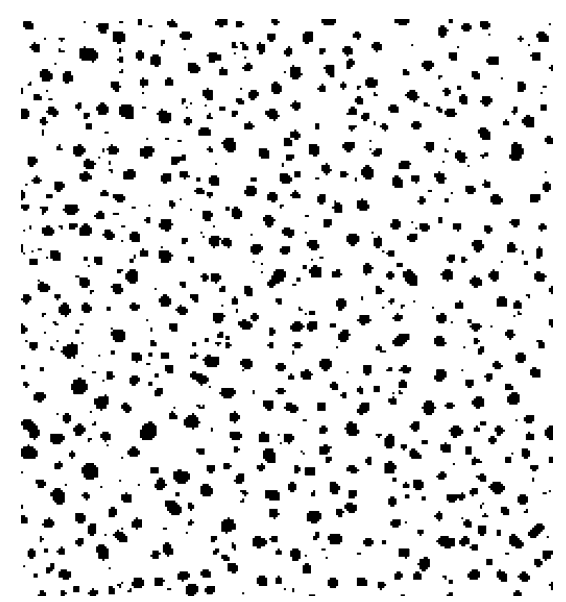

Fig. 5. TEM of particle distribution of PAC prepared by electrolysis process $\left(\mathrm{Al}_{\mathrm{T}}=2.0 \mathrm{~mol} \mathrm{1^{-1 }}, n=2.0\right)$.

size more than $100 \mathrm{~nm}$ with a broad distribution were observed. With the same concentration of $\mathrm{Al}_{\mathrm{T}}$ and larger $n$ value (2.5), the particle size distribution changed to a two band distribution. They were of sizes 8-15 and 192-425 nm, respectively. In addition, the mean diameters were 47 and $62 \mathrm{~nm}$ when the $n$ values were 2.0 and 2.5 , respectively.

The mean diameter of the $\mathrm{Al}_{13}$ polymer has been measured by small-angle X-ray scattering (SAXS) and found to be about $12 \AA$ [37]. Many researchers [26] have suggested that the $\mathrm{Al}_{13}$ polymer units could gradually form tenuous linear aggregates with $\mathrm{Cl}^{-}$acting to bridge the units (Fig. 3). They suggested that these aggregates could form rapidly and predominate if the rate of neutralization was rapid. Thomas et al. [38] provided evidence that, at least under some conditions, small aggregates of $\mathrm{Al}_{13}$ form that still produce a visible $63 \mathrm{ppm}$ resonance, albeit quite broad. Bertsch and Parker [39] have also made this observation in very dilute, partially neutralized solutions. In this paper, the particles sized in the $3-5 \mathrm{~nm}$ range analyzed by DLS might be $\mathrm{Al}_{13}$ and those of $8-15 \mathrm{~nm}$ might be small $\mathrm{Al}_{13}$ aggregates, while those of $110-220 \mathrm{~nm}$ were probably $\mathrm{Al}_{13}$ aggregates of chain-like cluster. The results of Table 2 also demonstrate that the percentage of particles sized $3-5$ and $8-15 \mathrm{~nm}$ were 18.5 and $45.6 \%$ respectively. The particles sized $110-220 \mathrm{~nm}$ only accounted for $21.8 \%$ of the 
Table 2

Particle size distribution by DLS $\left(\mathrm{Al}_{\mathrm{T}}=2.0 \mathrm{~mol}^{-1}\right)$

\begin{tabular}{llcll}
\hline Samples $(n)$ & Size distribution & Particle size distribution $(\mathrm{nm})$ & Proportion of particles $(\%)$ & Mean diameter $(\mathrm{nm})$ \\
\hline 2.0 & Trimodal distribution & $3-5$ & 18.5 & 47 \\
& & $8-15$ & 45.6 & 21.8 \\
2.5 & $110-220$ & 45.5 & 62 \\
& & $8-15$ & 45.3 & \\
& Bimodal distribution & $192-425$ & & \\
\hline
\end{tabular}

particles present. Thus, in the PAC of $n=2.0$, most of the hydroxy aluminium polymers existed as $\mathrm{Al}_{13}$ polymer or small aggregated $\mathrm{Al}_{13}$. From Table 2, it is observed that when the $n$ value increased from 2.0 to 2.5 , the particles sized 3-5 $\mathrm{nm}$ disappeared and the proportion of larger particles increased. We conclude that more $\mathrm{Al}_{13}$ aggregates of chain-like cluster were formed under these conditions.

\section{Conclusions}

The electrolysis process was employed to prepare nanosized PAC. The results of ${ }^{27} \mathrm{Al}$ NMR spectroscopy showed that significant quantities of the active species - $\mathrm{Al}_{13}$ polymer - were formed in PAC solutions at relatively higher concentrations of $\mathrm{Al}_{\mathrm{T}}\left(0.2-2.0 \mathrm{~mol} \mathrm{1^{-1 }}\right)$. For PAC of $\mathrm{Al}_{\mathrm{T}}=2.0$ mol $1^{-1}$ and $n=2.0$, the content of $\mathrm{Al}_{13}$ accounted for $65.6 \%$ of $\mathrm{Al}_{\mathrm{T}}$ and they were stable in the PAC solution for more than 6 months. Although more $\mathrm{Al}_{13}$ was formed at higher $n$ values, they did not persist in solution and gradually transformed to other polynuclear forms that were not detectable by ${ }^{27} \mathrm{Al}$ NMR spectroscopy.

The results of DLS and TEM analysis showed that most of particles existing in PAC prepared by the electrolysis process were in the nanometer size range. The particle size of PAC with $n=2.5$ was larger than that of $n=2.0$. For PAC of $\mathrm{Al}_{\mathrm{T}}=2.0$ mol $1^{-1}$ and $n=2.0$, the particle sizes exhibited a trimodal distribution with most of the $\mathrm{Al}_{13}$ present as single $\mathrm{Al}_{13}$ molecules and small aggregates of $\mathrm{Al}_{13}$.

\section{Acknowledgements}

The work was supported by the National Natural Science Foundation of China (Grant No. 50108016).

\section{References}

[1] J. Buffle, N. Parthasarathy, W. Haerdi, Water Res. 19 (1985) 7.

[2] P.H. Hsu, Water Res. 9 (1975) 1155.

[3] P. Thebault, J.M. Cases, F. Fiessinger, Water Res. 15 (1981) 183.

[4] W. Stumm, J.J. Morgan, J. Am. Water Works Assoc. 54 (1962) 971.

[5] W. Stumm, C.R. O'Melia, J. Am. Water Works Assoc. 60 (1968) 514.

[6] P.H. Hsu, Adv. Chem. Ser. 73 (1963) 115.

[7] R.F. Packham, I. Sheiham, J. Inst. Water Eng. Sci. 31 (1977) 96.

[8] B.A. Dempsey, R.M. Ganho, C.R. O’Melia, Presented at the Conference of the American Water Works Association, Miami, FL, 1982.

[9] G. Johansson, Acta Chem. Scand. 14 (1960) 771.

[10] G. Johansson, Acta Chem. Scand. 16 (1962) 403.

[11] G. Johansson, Ark. Kemi 20 (1963) 305.

[12] G. Johansson, Ark. Kemi 20 (1963) 321.

[13] J.W. Akitt, J.M. Elders, J. Chem. Soc., Dalton Trans. (1988) 1347.

[14] J.Y. Bottero, M. Axelos, D. Tchoubar, J. Colloid. Interf. Sci. 117 (1987) 47.

[15] P.M. Bertsch, G.W. Thomas, R.I. Barnhisel, Soil Sci. Soc. Am. J. 50 (1986) 825.

[16] J.T. Kloprogge, D. Seykens, J.W. Geus, J.B.H. Jansen, J. Non-Cryst. Solids 142 (1992) 87.

[17] J.T. Kloprogge, D. Seykens, J.B.H. Jansen, J.W. Geus, J. Non-Cryst. Solids 142 (1992) 94.

[18] P.M. Bertsch, Soil Sci. Am. J. 51 (1987) 825.

[19] R.S. Li, Basic Aluminum Chloride, Architecture Published House Pressed, China, 1981. 
[20] New Nippon Steel and Iron Co. Japan Patent 46598 (1975).

[21] G.G. Lu, J.H. Qu, H.X. Tang, Environ. Sci. 16 (1997) 522 (in Chinese).

[22] J.H. Qu, G.G. Lu, H.X. Tang, Chin. Environ. Sci. 18 (1998) 140 (in Chinese).

[23] G.G. Lu, J.H. Qu, H.X. Tang, Water Res. 33 (1999) 807.

[24] J.H. Qu, G.G. Lu, H.X. Tang, Acta Scientiae Circumstantiae 17 (1997) 423 (in Chinese).

[25] J.W. Akitt, A. Farthing, J. Chem. Soc., Dalton Trans. (1981) 1617

[26] G. Fu, L.F. Nazar, A.D. Bain, Chem. Mater. 3 (1991) 602.

[27] D.R. Parker, P.M. Bertsch, Environ. Sci. Technol. 26 (1992) 914.

[28] N. Parthasarathy, J. Buffle, Water Res. 19 (1985) 25.

[29] P.H. Hsu, J. Soil Sci. 127 (1979) 219.

[30] R.C. Turner, Can. J. Chem. 54 (1976) 1528.
[31] R.C. Turner, Can. J. Chem. 54 (1976) 1910.

[32] J.Y. Bottero, J.M. Tchoubar, F.F. Cases, J. Phys. Chem. 86 (1982) 3667.

[33] C. Brosset, G. Biedermann, L.G. Sillén, Acta Chem. Scand. 8 (1954) 1917.

[34] D.Z. Denney, P.H. Hsu, Clays Clay Miner. 34 (1986) 604.

[35] P.M. Bertsch, W.J. Layton, R.I. Barnhisel, Soil Sci. Soc. Am. J. 50 (1986) 1449.

[36] G. Furrer, C. Ludwig, P.W. Schindler, J. Colloid. Interf. Sci. 149 (1992) 56.

[37] J.Y. Bottero, M. Axelos, D. Tschoubar, J.M. Cases, J.J. Fripiat, F. Fiessinger, J. Colloid. Interf. Sci. 117 (1987) 47.

[38] F. Thomas, A. Masion, J.Y. Bottero, Environ. Sci. Technol. 27 (1993) 2511.

[39] P.M. Bertsch, D.R. Parker, The Environmental Chemistry of Aluminum (Chapter 4). CRC Press, Boca Raton (1996) 117. 